\title{
Development of Shading Tolerant Rice Varieties Suitable for Intercropping Cultivation in Agroforestry Systems
}

\author{
Aris Hairmansis ${ }^{1, *}$, Yullianida Yullianida, Rini Hermanasari, Angelita Puji Lestari \\ ${ }^{1}$ Indonesian Center for Rice Research, Jalan Raya 9 Sukamandi, Subang, West Java, Indonesia
}

\begin{abstract}
The Indonesian government continuously strives to increase rice production in an effort to meet the staple food needs of almost 270 million people and to turn Indonesia to become a rice exporter country. One of the strategic efforts is to expand the planted area of rice outside irrigated rice areas. Upland is one of the potential areas that continues to be developed to support the increase of national rice production. While upland is not an ideal ecosystem for rice plants to grow, the opportunity to produce rice in this ecosystem is promising, especially using rice as an intercropping in plantation. This effort requires the availability of adaptive varieties to low light intensity conditions. The breeding program to develop shade-tolerant rice varieties has been carried out by the Indonesian Center for Rice Research (ICRR) through the conventional breeding program. Breeding populations were produced by crossing local varieties, national leading varieties and introduced varieties. The selection of shading adaptive lines was carried out using both artificial shading and natural shading in the target plantation areas. New shade tolerant rice varieties have been recently released, namely Rindang 1 Agritan and Rindang 2 Agritan which have the potential to be utilized by farmers for intercropping rice cultivation in the agroforestry systems.
\end{abstract}

\section{Introduction}

For a lmost 270 million of Indonesia population [1] and most Asian countries, rice is currently still the main source of energy. The demand for rice will continuously increase in line with population growth. To meet these needs, various efforts are needed to increase rice production, among others, by improving cultivation technology and expanding agricultural land for food production [2].

In Indonesia, rice is produced in a wide range of agroecosystem including irrigated lowland, rainfed lowland, upland and swampy areas. About $95 \%$ of rice production in Indonesia is produced from lowland rice areas accounted for about 8.1 million ha [3]. Unfortuna tely, the area of fertile lowland rice tends to decline due to land conversion and land degradation. On the other hand, it is estimated that around 7.08 million ha of dry land are available and have the potential to be used for food crop cultivation including upland rice [4]. Therefore, the role of upland to support the susta inability of rice production in the future will be more significant.

Apart from being the main crop with a monoculture pa ttern, rice cultivation in the upland can be intercropped with plantation crops and industrial forest plantations [5]. Rice can be planted in between plantation crops such as oil pa lm, coconut, rubber and cacao, and industrial forest plantations such as te ak, acacia and meranti. In addition, upland rice is also potential to be planted in between of annual horticultural plantation such as orange trees, durian and others. Utilization of intercropping land between plantation can be implemented at the beginning after land clearing or when replanting is carried out. On these types of lands rice can be planted in between the main crops until the shade reaches $50 \%$ [6]. The area of plantation and industrial forest plantation which are potential for upland rice cultivation was estimated to be reaching 2 million hectares per year [5]. The integration between rice and plantation is one of implementations of a groforestry system that can provide environmental, economic and socialbenefits [7]. Apart from

${ }^{*}$ Corresponding author : a.hairmansis@gmail.com 
being an effort to support increasing national food production, the system would increase the efficiency of land resources when the main crops are not yet productive and increase farmers' income.

Until now the area of upland which has been utilized for rice production remains very limited when compared to the available potential land. The area of dry land cultivated for rice is around 1.1 million hectares per year [3]. Moreover, the productivity of upland rice in Indonesia was still very low, a round 3.2 tonnes per hecta re, far below the average rice productivity in irrigated lowland which was 5.3 tonnes per hectare [8]. Rice cultivation in dry land is constrained by various problems including drought, soil acidity, low soil fertility, and blast disease caused by the fungus Pyricularia grisea [8]. In areas where rice is cultivated as intercropping in between plantation, shading become the main problem which causing yield reduction.

To develop rice as an intercropping crop, adaptive varieties with shaded environments are needed. Through the breeding program new shading tolerant rice varieties have been developed and relea sed to the farmers. This paper will discuss the development of the new shading tolerant rice varieties which are suitable for cultivation of rice as an intercropping in agroforestry system.

\section{Effect of shading on rice growth and the adaptation of rice to shading stress}

Solar radiation has important roles on the rice plant growth and yield. The presence of shading in intercropping system would disrupt photosynthetic activity, which causes inhibition of plant growth rates and reduces yields $[9,10]$. The shading generally causes an increase in plant height, decreases the number of productive tillers, delays flowering, decreases gra in filling, increases empty grain and ultimately reduces yield of rice $[11,12]$.

Rice varieties showed varied responses against shading. The effect of shading on the reduction of plant photosynthesis rate in tolerant varieties was lower in compare to sensitive varieties [13]. Tolerant va rieties a lso showed higher levels of chlorophyll a and chlorophyll $a / b$ ratios than sensitive varieties under shaded environment [14]. The increase in chlorophyll content in shade-tolerant varieties is suggested to be a plant adaptation response that helps plants to efficiently utilize light and increase the rate of photosynthesis [10], causing tolerant varieties had higher number of tillers and better gra in filling under shade stress conditions

\section{Development of shading tolerant rice varieties}

Utilization of land resources in between plantation for rice production would require shading tolerant rice varieties. However, in addition to having shading tolerance tra it, the varieties for intercropping must have characteristics which are needed to adapt to other abiotic and biotic stresses in upland such as drought, soil acidity, aluminium toxicity, phosphorous deficiency, and blast disease [8]. To obta in superior rice varieties that are adaptive to abiotic and biotic stresses in upland as intercropping system, gene sources for important traits are needed such as tolerance to various environmentalstresses, having good a gronomic performance and good gra in qua lity. Germplasm for genetic resources in the improvement of upland rice varieties involve trad itionalvarieties, improved varieties and introduction varieties.

In developing shading tolerant rice varieties, it is essential to use efficient selection method to select the best performance lines under shading environment. Screening to identify tolera nt varieties could be done using artificial shading stress or using natural shading in target area of plantation (Figure 1). A number of studies have used shade net to select adaptive lines to low light condition and showed effectiveness of this method to screen rice breeding lines $[12,15,16]$. The method mostly used in experimental station with limited number of breeding population. For instance, Lestari et al. [16] has identified 23 tolerant lines out of 200 lines under artificial screening method. 


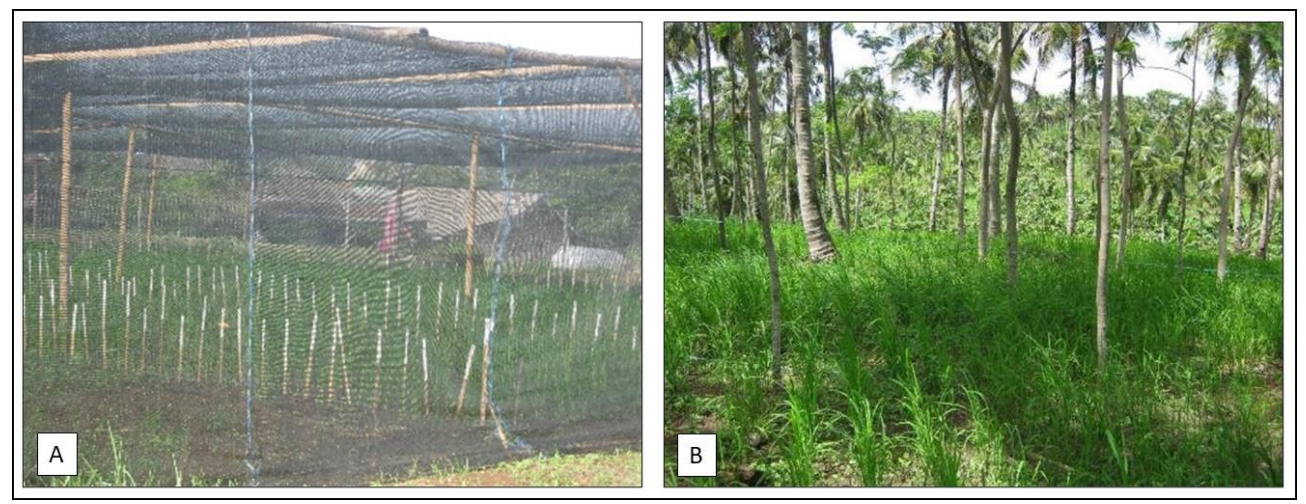

Fig. 1. (A) Artificial screening to select shading tolerant rice varieties using shade net in Muara experimental station of Indonesian Center for Rice Research. (B) Coconut plantation in Sukabumi district of West Java as experimental site for selection of shading tolerant rice varieties.

However, for a large breeding population, screening in target areas would be more effective compare to artificial screening system. Furthermore, selection of rice breeding lines in target environment allowing breeder to determine the performance of rice lines in response to shading and other environmentalstresses which present in upland such as drought, soil acidity, phosphorous deficiency and blast disease. An example of project site for selection of shading tolerant rice varieties is the tall coconut plantation in Sukabumi district which has been used for consecutive rice breeding cycle (Figure 1). In this site, rice breeding lines in different generation were evaluated. Early generation materials were grown as pedigree nursery, while advance materials were evaluated in replicated yield trials. Selected advanced breeding lines were then evaluated in the multilocation yield trials to determine their yield stability.

During the wet sea son of 2016/2017, the multilocation yield trials of shading tolerant rice lines were conducted in different intercropping system by evaluating the performance of rice lines under different plantations including coconut, teak, albizia, rambutan and rubber (Figure 2) (Hairmansis et al. unpublished data). As comparison, the materials were also grown in other sites as monoculture crop without any shading stress. The performance of rice breeding lines was evaluated in replicated trials where each rice breeding line was grown in a $18.9 \mathrm{~m}^{2}$ plot. Result from the multilocation yield trials clearly indicated that gra in yield of rice breeding lines grown as intercropping was lower than as monoculture. While in monoculture crop systems, the upland rice breeding lines showed grain yield in the range of 5.55 to $6.18 \mathrm{t} \mathrm{ha}^{-1}$, under intercropping systems the grain yield average of rice breeding lines range from $2.55 \mathrm{t} \mathrm{ha}^{-1}$ (intercropping with albizia) to $4.44 \mathrm{t} \mathrm{ha}^{-1}$ (intercropping with teak) (Hairmansis et al., unpublished data). However, under different intercropping system, rice breeding lines showed varied response in grain yield indicating the presence of genotype and environment interaction which allow the selection of best performer lines for intercropping system. 


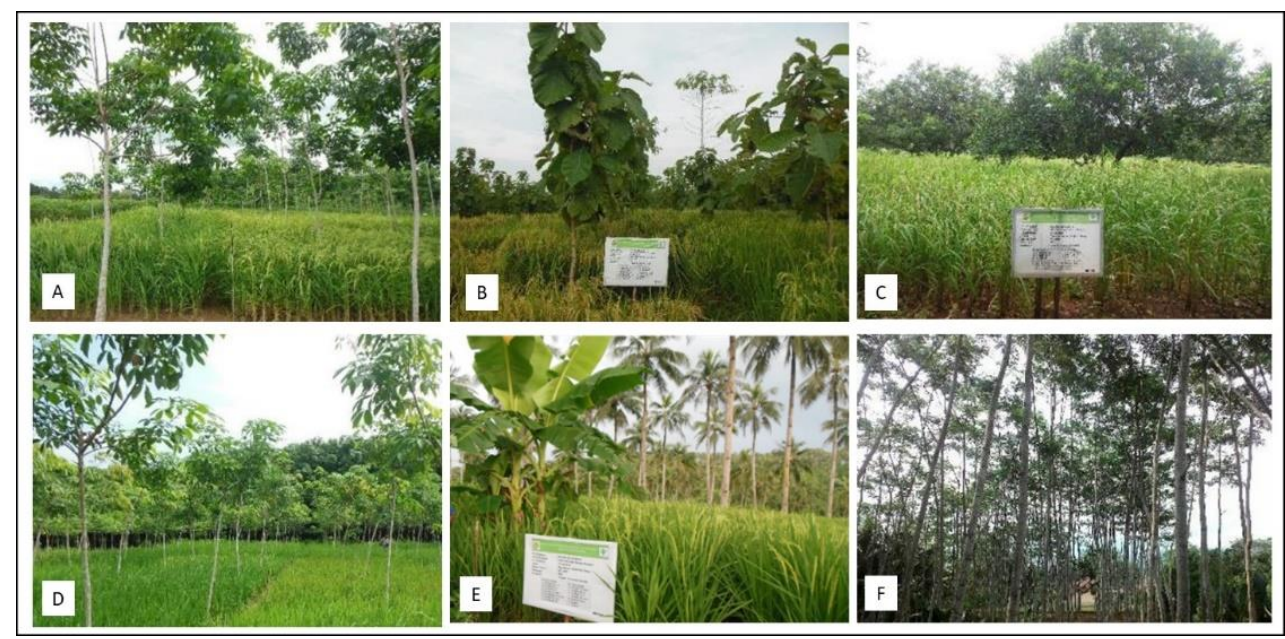

Fig. 2. Sites for multilocation yield trials of advance rice breeding materials as intercropping under (A) rubber plantation in Central Lampung, (B) teak plantation (Indramayu), (C) rambutan plantation in Subang, (D) rubber plantation ini East Lampung, (E) coconut plantation in Sukabumi and (F) albizi plantation in Banyumas during wet season of 2016/2017.

Based on the performance in the multilocation yield trials, there are two rice breeding lines which have been released as new rice varieties having shading tolerance and suitable for intercropping system, namely Rindang 1 Agritan and Rindang 2 Agritan. Rindang 1 Agritan has avera ge grain yield of $4.62 \mathrm{t} \mathrm{ha}^{-1}$, while Rindang 2 Agritan has avera ge gra in yield of $4.20 \mathrm{t} \mathrm{ha}^{-1}$ (Table 1). The major differences between Rindang 1 Agritan and Rindang 2 Agritan was the cooked rice texture. Rindang 1 Agritan has hard texture, while Rindang 2 Agritan has soft rice texture. This difference would allow farmers to choose the varieties based on the consumers preference on gra in quality in their region.

Table 1. Characteristics of shading tolerant rice varieties Rindang 1 Agritan and Rindang 2 Agritan [17]

\begin{tabular}{|l|c|c|}
\hline Characteristics & Rindang 1 Agritan & Rindang 2 Agritan \\
\hline Maturity (days after seedling) & \pm 113 & \pm 113 \\
\hline Plant height (cm) & \pm 130 & \pm 138 \\
\hline Grain yield ( $\left.\mathrm{t} \mathrm{ha}^{-1}\right)$ & 4.62 & 4.20 \\
\hline 1000 grain weight $(\mathrm{g})$ & \pm 27.6 & \pm 31.3 \\
\hline Amylose content $(\%)$ & \pm 26.4 & Soft \\
\hline Cooked rice texture & Hard & \\
\hline
\end{tabular}

\section{Conclusion}

Implementation of intercropping of rice in between plantation has potential to be scaled up by utilizing new shading tolerant rice varieties Rindang 1 Agritan and Rindang 2 Agritan. New shading tolerant rice varieties which have been developed are expected to be adopted by farmers in a groforestry system to ga in environmental, economic and social benefit, and more importantly supporting the susta inability of rice production in Indonesia.

Research on the development of shading tolerant rice varieties was funded by the Indonesian Agency for Agricultural Research and Development (IAARD) through the budget implementation list of ICRR. 


\section{References}

1. BPS-Statistics Indonesia, Statistical Yearbook of Indonesia 2020, BPS-Statistics Indonesia, Jakarta (2020)

2. D. K. Ray, N. D. Mueller, P. C. West, J. A. Foley, PLoS ONE, 8, 6 (2013)

3. Center for Agricultural Data and Information System, Agricultural Statistics 2018, Center for Agricultural Data and Information System, Jakarta (2018)

4. A. Mulyani, S. Ritung, I. Las, Jurnal Litbang Pertanian, 30, 2 (2011)

5. H.M. Toha, K. Pirnga di, K. Permadi, A.M. Fagi, Padi Inovasi Tenologi Produksi Buku 2, LIPI Press, Jakarta (2009)

6. D. Sopandie, Trikoesoemaningtyas, Iptek Tanaman Pangan, 6, 2(2011)

7. S. Jose, Agroforestry systems, 76, 1 (2009)

8. A. Hairmansis, Yullianida, Supartopo, Suwarno, Iptek Tanaman Pangan, 11, 1 (2016)

9. Q. Liu, X. Wu, B. Chen, J.Ma, J. Gao. 2014, Rice Science, 21, 5 (2014)

10. L. Wang, F. Deng, W.J. Ren, 2015, Field Crops Research 180: 54-62.(2015)

11. S. Singh, IRRN, 30, 2(2005)

12. A. Hairmansis, Yullianida, Supartopo, A. Jamil, Suwarno. Biodiversitas, 18, 3 (2017)

13. D. Jiao, X. Li, Photosynthetica, 39,2 (2001)

14. D. Sopandie, M. A. Chozin, S. Sastrosumarjo, T. Juha eti, Sahardi, Hayati, 10, 2 (2003)

15. P. Sa smita, Jurnal Agrikultura, 19, 1 (2008)

16. A. P. Lestari, A. Hairmansis, E. S. Mulyaningsih, Y. Sulistyowati, IOP Conf. Series: Earth and Environmental Science, 591 (2020)

17. BBPadi, Deskripsi Varietas Unggul Padi, BBPadi, Sukamandi(2018) 